\title{
The corporate philanthropy and legitimacy strategy of tourism firms: A community perspective ${ }^{1}$
}

\author{
Caiping Wang ${ }^{a}$, Honggang $\mathrm{Xu}^{\mathrm{b}}$ and Gang Lic \\ a International School of Business \& Finance, Sun Yat-Sen University, Guangzhou, China; \\ b School of Tourism M anagement, Sun Yat-Sen University, Guangzhou, China; \\ c School of Hospitality and Tourism M anagement, University of Surrey, Guildford, UK
}

\begin{abstract}
Corporate philanthropy (CP) is receiving increased attention, especially in transitional countries, such as China. Focusing on Chinese tourism attraction companies that operate on public tourism resources and have close relationships with their surrounding communities, this study investigates the factors driving firms' CP behaviour from a community perspective. Hypotheses are developed under the legitimacy framework. Probit and tobit regression models are used with data gathered from listed tourism attraction companies in China between 2000 and 2015. Three main findings are obtained. First, tourism attraction companies engage in CP more actively than other companies in the tourism industry. Second, three community-related features are significant drivers of tourism attraction firms' CP: unbalanced economic development, fierce business competition within the community and scarce educational resources. Third, the economic contribution of tourism partially moderates the associations between community features and tourism attraction firms' $\mathrm{CP}$. Further interviews with top managers of selected companies confirm the findings of the above statistical analysis. Both the theoretical and practical implications of the findings are discussed at the end of the paper.
\end{abstract}

Keywords: Corporate social responsibility; strategic corporate philanthropy; public tourism resources; legitimacy strategy; dual economy

\section{Introduction}

Corporate philanthropy (CP) has long been a key component of corporate social responsibility (CSR). In the traditional account of CSR presented by Carroll (1991), CP is at the top of the CSR pyramid, above economic, legal and ethical responsibilities. It is labelled as discretionary and regarded as voluntary rather than obligatory firm behaviour. In the

\footnotetext{
1 The paper should be cited as follows:

Wang, C., H. Xu and G. Li (2018). The Corporate Philanthropy and Legitimacy Strategy of Tourism Firms: A Community Perspective. Journal of Sustainable Tourism, DOI: 10.1080/09669582.2018.1428334.
} 
recent literature, $\mathrm{CP}$ has been regarded as an old-fashioned, ineffective way of managing a firm's relationship with society (Liket $\&$ Simaens, 2015). This may be due to the expectation that firms should provide constructive support for the local community rather than simply donating money. In practice, however, CP is still actively performed by firms in both developed and emerging economies (Liket $\&$ Simaens, 2015). It is one of the main measures used by firms to fulfil their CSR (Hill, Stephens \& Smith, 2003), and many individuals or organisations even conceptualise CSR as CP (Liket \& Simaens, 2015). In addition, CP is increasingly considered to be a strategic dimension of CSR (e.g., Bronn \& Vidaver-Cohen, 2009). Studies in this area demonstrate that CP can help to improve corporate competitiveness (Van Cranenburgh \& Arenas, 2014). CP is operationalised as firms' pursuit of greater legitimacy as perceived by their external stakeholders (Chen $\&$ Chao, 2016; Wang \& Qian, 2011), and accordingly, strategic CP is broadly defined as the "giving of corporate resources to address non-business community issues that also benefit the firm's strategic position and ultimately, its bottom line" (Saiia, Carroll, \& Buchholtz, 2003, p. 170).

Strategic $\mathrm{CP}$ is favoured because it builds close relationships between businesses and their local communities. CP often has benefits for the community, such as educational advancement, health and welfare support and poverty alleviation (Weeden, 2015). Strategic $\mathrm{CP}$ is acknowledged as an important means of executing CSR to promote community involvement and relationship development (Brammer \& M illington, 2005; Hedin \& Ranangen, 2017). Meanwhile, the interpretations, norms and values of the community can serve as standards for legitimising corporate philanthropic behaviours (Marquis, Glynn, \& Davis, 2007). How are a firm's CP behaviours affected by its local community? It is critical to answer this question to deepen our understanding of CP. Generally, CP has been emphasised by researchers as a means of building close connections with the community. CP helps firms to relieve institutional pressure from the community, improve their reputation, secure legitimacy and eventually increase their competitiveness (Marquis et al., 2007; Van Cranenburgh \& Arenas, 2014). Therefore, the legitimacy strategy related to institutional motives provides a useful theoretical framework for examination of firms' CP behaviours at the community level.

This study addresses the above question by exploring whether and how firms' CP behaviours are impacted by their respective communities, using the theoretical framework of legitimacy. The empirical findings are drawn from various listed Chinese tourism attraction companies that operate on public tourism resources, such as national parks (hereafter "attraction companies").

First, as China represents the world's largest emerging market and transitional economy, Chinese CP has unique characteristics. CP makes up the largest proportion of Chinese philanthropic activities. In the Chinese transitional context, Chinese CP tends to be a response to government policies or other forms of intervention. For example, CP is 
advocated by the Chinese central government as a measure for "societal harmonisation". Thus, CP has become a key indicator of local governments' performance (Cao \& Fu, 2015). Many firms actively develop and deploy philanthropic strategies in line with the social expectations of local governments, enabling them to build good informal relationships with government agencies, which play a significant role in facilitating firms' operations (Cao \& Fu, 2015; Chen \& Cao, 2016). This is especially important for attraction companies that operate in less developed areas, in which local governments face greater pressure to supply public goods. Almost all of the listed attraction companies surveyed have chosen to donate to their communities. For example, Lijiang Yulong Tourism Co., Ltd (Lijiang Tourism) gave about USD600,000 to its local community in 2015. This funding is used to improve the management of small tourism businesses, promote agricultural product development, support educational, cultural and healthcare activities and so on.

Second, this kind of relationship plays a critical role in enabling attraction companies to obtain social legitimisation from local governments and communities. The marketisation of the public resources operated by attraction companies is authorised with high local community expectations and the promise of economic development (Ryan, Zhang, \& Deng, 2011). However, the modern attraction management model also creates a dual economy at the local level, typically characterised by the co-existence of a few modern tourism businesses and a large number of less sophisticated small businesses in surrounding communities. This is even more noticeable in cases of mass tourism development, as in China. Mass tourism development facilitates the growth of a modern tourism production system, comprising attraction companies, modern transport companies, hotel chains and large suppliers. However, this brings challenges for small informal businesses (Xu, Zhu, \& Bao, 2016). For example, the developed management system of the Eemeishan attraction company has deprived local residents of the chance to make a living as tour guides or through other tourism business opportunities (Bai, 2014). The structure of this dual economy fails to meet the needs of either local governments or communities, and can even lead to serious conflict between attraction companies and local communities (Bai, 2014). Such conflict jeopardises social harmony and sustainable community development. In the long term, it may also result in legitimacy crises for attraction companies (Wang $\&$ Qian, 2011).

The research question posed in this study is addressed first by investigating whether attraction companies that attempt to meet community expectations engage in CP more actively than other companies in the same industry. An affirmative answer is obtained through probit regression analysis. Next, the possible causes of CP are investigated by adopting the legitimacy strategy framework, and the effects of these causes on CP are tested using the tobit method. The results suggest that three community-related factors, namely economic divergence between a firm's surrounding community and local urban districts, business competition within the community and scarce educational resources, significantly 
impact attraction companies' CP behaviour. Last, as suggested by M arquis et al. (2007), the moderating effects of the economic contribution of the local tourism industry on the relationships between community-related factors and $\mathrm{CP}$ are examined.

This study thus contributes to the CP literature not only through its unique case study but also through its community-specific perspective. To the best of our knowledge, few studies have focused on the CP activities of firms operating on public resources; a notable exception is a study by Zhang, Zhu and Hua (2013), who qualitatively analysed the CP of coal enterprises. As firms operating on public resources have unique characteristics due to their operating assets, their CP should be investigated specifically. Next, most listed Chinese attraction companies operating on public tourism resources are state-owned, with high expectations of their social contribution. As a result, the relationships between these companies, local governments and communities are complicated. Investigating attraction companies in the Chinese transitional context may open up a new stream of CP literature. Last and most importantly, attention to CP in the tourism field is still scarce, with very few studies examining firms' achievements through particular philanthropic projects (Polonsky et al., 2013; Weeden, 2015). No researchers to date have empirically tested the impact on a firm's CP of its local community, either in the tourism field or in the broader CP literature. Thus, the investigation in this study is expected to enrich both the tourism literature and the literature on $\mathrm{CP}$.

\section{Literature review and hypothesis development}

\section{Philanthropy, corporate philanthropy and the legitimacy strategy framework}

Philanthropy has traditionally been defined as "universal goodwill towards fellow humans"

(Novelli, M organ, M itchell, \& Ivanov, 2015, p. 825). Today, however, more emphasis is placed on the active promotion and support of social welfare than on human goodwill alone (Novelli et al., 2015). Specifically, philanthropy is generally associated with the supply of public goods or other support for such provision, which is especially significant in developing countries (Van Cranenburgh \& Arenas, 2014). Novelli et al. (2015) further distinguished philanthropy into three overlapping approaches: traditional, modern and post-modern. Strategic CP falls into the category of modern philanthropy, as it emphasises a business's opportunity to use corporate resources to enhance its competitiveness through direct engagement in innovation and problem solving with the surrounding community.

Strategic CP is also strongly connected with global corporate citizenship and CSR (Novelli et al., 2015). As mentioned above, CP has traditionally been taken as a discretionary responsibility, positioned at the top of the CSR pyramid (Carroll, 1991). However, strategic CP has been found to play an important role in CSR practices (Liket $\&$ Simaens, 2015). It is connected with two key motivations for CSR: instrumental and institutional. The former 
stresses the managerial drive to achieve direct profit or revenue, and the latter emphasises institutional pressure from key stakeholders (Bronn \& Vidaver-Cohen, 2009). As CP forges close relationships between firms and their communities (Liket \& Simaens, 2015; M arquis et al., 2007), the social goal of behaving according to the community's norms, values or beliefs goes beyond the simple motive of making a profit (Bronn \& Vidaver-Cohen, 2009). CP is increasingly defined as the integrated application of a firm's resources to address the social expectations of key stakeholders and thereby obtain both organisational and social benefits in the long term (Thorne, Ferrell, \& Ferrell, 2003). From this perspective, the pursuit of legitimisation provides an effective framework for exploration of firms' $\mathrm{CP}$ as connected with both communities and local governments (Wang \& Qian, 2011).

Legitimacy is recognised as the "generalized perception or assumption that the actions of an entity are desirable, proper or appropriate within some socially constructed system of norms, values, beliefs and definitions" (Suchman, 1995, p. 574). As every social institution operates in society with an expressed premise or an implied social contract (Chen $\&$ Chao, 2016), a firm's legitimacy depends on the perceived degree of conformity between its actions and societal expectations (Chen \& Chao, 2016). Generally, due to the divergence between corporate performance and societal expectations, gaps may arise between a firm's legitimacy status and the expectations of external stakeholders (Sethi, 1979). It is critical for corporate managers to fill these gaps to prevent legitimacy crises (Chen \& Chao, 2016). Philanthropy is an effective means of closing such gaps. The supply of 'public goods' to communities allows firms to share the responsibilities of local governments and helps them to build close connections with the community. This can improve a firm's legitimacy by improving its corporate image, fulfilling its stakeholders' expectations, soliciting recognition for its moral leadership, compensating for its weak social performance in other areas and maintaining its long-term competitiveness (Bronn \& Vidaver-Cohen, 2009). In addition, building close relationships with key stakeholders such as the local government and the community can also help a firm to gain approval from both the public (social legitimacy) and the government (political legitimacy), which eventually enables it to gain political access and other resources (Wang \& Qian, 2011).

The influence of CP on firms' legitimacy has been reported in a large body of literature (Bronn \& Vidaver-Cohen, 2009; Chen \& Chao, 2016; Wang \& Qian, 2011). In the tourism field, for example, Weeden (2015) found that cruise firms gained social legitimacy for their operations by providing financial support for local schools in Haiti. Polonsky et al. (2013) analysed the effects of the Turkish "Respect for History" project, designed to increase business opportunities and improve infrastructure in local communities. They found that the residents held more positive views on the company sponsoring the project after the completion of the project.

However, it remains unclear whether the legitimacy pressure exerted by local 
communities drives firms' CP actions adversely or significantly. No research has yet addressed this issue empirically. The implied social undertaking to promote community and economic development is particularly significant for Chinese attraction companies, as they obtain authorisation from the government to operate on public tourism resources (Wang \& $X u, 2014)$. In China, as a developing socialist country, local governments take the pursuit of community harmony and development as their primary task (Cao \& Fu, 2015). This exerts greater legitimacy pressure on firms, which are required to fulfil the social expectations not only of the community but also of local governments. Thus, this study uses a sample of typical attraction companies to explore the influence of legitimacy pressure on firms' CP. The implied social contract formed in the Chinese transitional context is analysed with reference to the legitimacy framework in the following section.

\section{Corporate philanthropy, local community and sustainability}

Firms' understanding of their surrounding communities may vary considerably. Bowen, Newenham-Kahindi and Herremans (2010) emphasised the social meaning of interests shared by individuals or groups of citizens in the community, but others have highlighted the geographical area in which the company or its main business is located (e.g., Hedin \& Ranangen, 2017; Marquis et al., 2007). In practice, both geographical proximity and social meaning affect the connections between a firm and its community. Most CP activities are directed towards the local community (Liket \& Simaens, 2015; Zhang et al., 2013) and assist firms' engagement with their communities. CP can benefit both firms and communities in many ways (Polonsky et al., 2013). In addition to the advantages for firms gained under the legitimacy framework discussed above (Bronn \& Vidaver-Cohen, 2009), community livelihoods can be improved by the development of a firm's philanthropic projects (Polonsky et al., 2013). Investigating the contribution of travel philanthropy to sustainable sovereign-state-led and community-led development initiatives, Novelli et al. (2015) debated the positive role of travel philanthropy in stimulating sustainable development in Sub-Saharan Africa. Meanwhile, in the general management field, the role of CP in promoting sustainability was recognised by the United Nations (UN) in its 2030 Sustainability Agenda (UN, 2015).

To summarise, a firm's CP actions contribute to the sustainable development of its surrounding community economically, socially and environmentally. Conversely, the developmental features of a community may affect a firm's CP behaviours, as different communities have their own features. From the perspective of sustainability, specific issues such as poverty alleviation, superior educational resources and job opportunities reflect the particular economic, social and institutional environments of different communities. So, how do these community features impact firms' CP? To date, only Marquis et al. (2007) have proposed a theoretical framework for viewing corporate social actions through a community lens, which provides a good opportunity for further investigation. The relationships between 
attraction companies and communities also provide a useful context for our investigation. In addition, given the availability of data and the empirical contexts of the communities that surround the tourism attraction sites in this study, community features are pooled into three categories - economic, business competition and education - to further investigate the impact of community features on firms' $\mathrm{CP}$.

\section{Hypothesis development based on the legitimacy strategy framework}

China's transitional institutional context must be considered when conducting research on Chinese attraction companies operating on public tourism resources (Chen \& Cao, 2016). First, the implied social contract to promote local community development is the initial target for these companies. By the end of the last century, many public tourism resources had been developed as tourist attractions by local governments to promote the sustainable development of the local economy, community and environment (Ryan et al., 2011; Wang \& $\mathrm{Xu}, 2014)$. Later, the mode of operation of these attraction sites was reformed, and their ownership and operational rights were separated. The attraction companies were then allowed to begin operating public tourism resource attractions, and were even listed in the securities market. However, the initial expectations of community development were also transferred to these enterprises.

Second, social expectations of tourism development were strengthened by mass tourism development. In many less-developed areas, listed attraction companies tend to be the only modernised businesses (Wang $\&$ Xu, 2014), and as resources for development are very limited, local governments normally use all available resources to facilitate mass tourism development ( $X u$ et al., 2016). Communities often sacrifice their own development rights to attraction companies, thereby reducing governmental financial support. The development priority given to attraction companies increases both local governments' and communities' expectations of these companies' contribution to local sustainable development (Ryan et al., 2011).

Third, Chinese society pays considerable attention to attraction companies' operations. In China's planning economy period, when no attraction companies had yet been established, almost all public companies and institutions were asked to provide their employees with social welfare, such as hospitals and schools, and these services were sometimes extended to surrounding communities. After the introduction of economic reform and the open-door policy in 1978, attraction companies were no longer required to provide these services; nevertheless, companies are still expected to provide social welfare and public goods to the local community. This is especially the case for listed attraction companies.

However, gaps inevitably arise between the social expectations of formal companies, small businesses and surrounding communities (Xu et al., 2016). With China's mass tourism boom, attraction companies have grown dramatically, and their monopoly on sales of entry tickets and auxiliary services has brought them enormous financial returns (Wang $\& X u, 2014$ ). 
However, communities and residents have lagged behind in organising and integrating themselves into this mass production supply system ( $X u$ et al., 2016). Meanwhile, opportunities for local communities to develop other forms of business, such as agriculture, have generally decreased as tourism has become more important. The widening gap between the two frustrates both local communities and governments, and often leads to conflict between communities and firms. This harms attraction companies' legitimacy status, and may even lead to social and political legitimacy crises (Chen \& Chao, 2016; Wang \& Qian, 2011).

The marketisation of public tourism resources should be conditional upon good external public recognition and social relationships. In less developed areas with poor institutional services, firms depend more on informal relationships to support their operations (Li \& Zhao, 2015; Wang \& Qian, 2011), and CP has been found to be an effective strategy for building such relationships with communities and local governments, improving firms' reputation and eventually gaining firms both social and political legitimacy (Chen, Jiang, \& Yu, 2015). This can decrease attraction companies' business risk and even improve their access to other political resources (Chen et al., 2015; Wang \& Qian, 2011). Thus, attraction companies subject to greater expectations from their surrounding communities more actively engage in CP. To illustrate the distinct characteristics of this kind of attraction company in terms of their stronger ties with surrounding communities, non-attraction tourism enterprises that mostly operate on privately owned assets and are located in metropolises are also included in this study for comparison. Given the locations and ownership of the assets of these non-attraction enterprises, CP appears to be more necessary for attraction companies. Therefore, an overall hypothesis is proposed, as follows.

$\mathrm{H1}$ : Attraction companies engage more actively in community-based CP than other enterprises in the tourism industry.

Although attraction companies may more actively donate than other companies in the tourism industry, their CP strategies differ between communities. To show how a community may influence a firm's CP in the Chinese context, three factors reflecting Chinese community expectations are presented here. The first factor is economic. The communities that surround tourism attractions are generally located in rural areas, which are less developed than urban districts in the same regions. Unbalanced economic development is a crucial factor limiting a community's long-term sustainability (UN, 2015), and has caused considerable social conflict during tourism development (Bai, 2014). This study proposes an index reflecting the economic divergence of a firm's surrounding community from urban districts in the same region. A large economic divergence indicates a severely divided dual economy and a large gap in expectations. The failure to satisfy the expectations of their surrounding communities may lead to a serious legitimacy crisis for attraction companies, driving firms to actively address this issue through CP. Therefore, the wider this economic 
divergence, the more important it is for an attraction company to engage in $\mathrm{CP}$.

$\mathrm{H} 2 \mathrm{a}$ : Economic divergence between the local community and urban districts may positively influence an attraction company's CP behaviour.

The second factor is business competition within a community. Generally, tourist attraction sites are surrounded by villages, and communities in local villages tend to prioritise big attraction companies over small firms in terms of business development opportunities (Ryan et al., 2011). A lack of cooperation between these small firms often leads to fierce competition for the limited tourism business opportunities left to them (Xu et al., 2016), potentially resulting in environmental deterioration and economic losses. This not only impedes the economic and social development of the surrounding community, but may incite conflict between the less developed community and the sophisticated attractions. Attraction companies tend to address this problem by donating funds to the community to train residents to contribute to their business operations (e.g., Lijiang Tourism) or to develop their skills for other job opportunities (e.g., Huangshan Tourism Development Co., Ltd). The fiercer the competition within a community, the greater the tension and potential for conflict between the community and attraction companies, and thus the greater the need for attraction companies to engage in CP. In this way, attraction companies help local residents to use tourism resources sustainably and realise their own development. Eventually, this improves the firms' reputation in the community and secures their legitimacy.

$\mathrm{H} 2 \mathrm{~b}$ : Competition for tourism business opportunities within the surrounding community may positively influence an attraction company's $\mathrm{CP}$ behaviour.

The third factor is the degree of educational resources in a community, a criterion noted in the UN's sustainability agenda (UN, 2015). Education has traditionally been taken very seriously in Chinese society, as a critical component of an individual's or a family's life outcomes (Guthrie, Arum, Roksa, \&Damaske, 2008). Supplying superior educational resources is an important target of community development in China; however, educational resources are unevenly distributed between areas. Therefore, local governments must take responsibility for developing primary education. This situation became serious after the implementation of a financial reform of primary education in the 1990s (Zhou, 2015), and its severity increased when local governments were forbidden from collecting traditional educational funding, such as taxes, surcharges, tuition and miscellaneous school fees, in the late 1990s (Zhou, 2015). These measures exerted great financial pressure on both local governments and communities in the less developed central and western regions of China to raise education funds (Zhou, 2015). But it also offered attraction companies an opportunity to increase their social and political legitimacy by fulfilling expectations of community development, especially in areas with scarce educational resources. Indeed, educational support is a common component of attraction companies' philanthropic strategies, and the 
fewer the educational resources in its community, the more likely an attraction company is to engage in CP practices.

$\mathrm{H} 2 \mathrm{c}$ : The concentration of a community's educational resources may negatively influence an attraction company's CP behaviour.

Donation or giving incurs costs for a firm. The use of this strategy by an attraction company depends on its costs and potential advantages as evaluated by the company (Tan \& Tang, 2016). Although CP is a good method of improving a firm's social and political legitimacy, it is not the only one. Attraction companies can also gain legitimacy by negotiating with local governments and obtaining their support (Guthrie et al., 2008; Zhang et al., 2013). Generally, contributing to the local economy makes an industry more successful, and local governments tend to grant firms in this industry more favourable policies. Listed attraction companies are often the biggest tourism businesses in the local area and make the greatest contribution to tourism development (Wang $\& X u, 2014$ ). Thus, the industrial contribution of tourism is a good indicator of an attraction company's power to bargain with the local government. If the local government helps the listed attraction company to solve its problems with the local community, the firm may feel less pressure to use a CP strategy. Therefore, the following hypothesis is proposed.

H3: The economic contribution of tourism inversely moderates the relationships between community features and an attraction company's CP behaviour.

\section{Methodology}

This study adopts a mixed-methods approach. The main method is quantitative, allowing the research hypotheses to be empirically tested. The quantitative analysis is supplemented by a small number of interviews conducted to verify the findings of the quantitative analysis and to further explain the operation of the detected causal relationships.

\section{Samples and data}

The study focuses on listed attraction companies in China: the most significant attraction companies operating on famous public tourism resources. The study is facilitated by reliable access to financial and other public information. Nine listed attraction companies are defined and included according to their main business, and 41 other listed tourism companies are used as a paired sample. Ninety-eight firm-year observations and 279 firm-year observations from 2000 to 2015 are obtained for the listed attraction companies and paired companies, respectively. In the period under study, some companies left the tourism field and others entered the field through diversification or initial public offerings. As a result, different years are associated with different numbers of sample observations. Only firms with tourism as their main source of revenue are included. Special treatment and particular transfer companies are excluded from the sample due to their special trading modes. 
All of the selected financial and non-financial data on the listed companies are drawn from the China Stock Market Accounting Research database. Regional data are collected from the 'Statistical Communique on National Economy and Social Development' documents published by local governments. Information on the tourist attractions operated locally by the listed companies is collected via search engines (e.g., www.baidu.com) and verified by comparison with the official websites of the tourist attraction sites. CP data are manually collected from the annual financial reports of the sampled firms. These data are presented as one item, "non-operating expenses", in the firms' annual financial reports.

\section{Variables and models}

This study investigates community-related factors that influence listed attraction companies' $\mathrm{CP}$ behaviour. $\mathrm{CP}$ behaviour is examined in two dimensions: the probability of engaging in $\mathrm{CP}$ and the level of CP engagement. Thus, two dependent variables are included. The first is a dummy variable (Dphi) that indicates a firm's probability of donating, equalling 1 if a firm donates and 0 otherwise. The second comprises an absolute value ( $\mathrm{LnPhi}$ ) and a relative value (PhiR) of CP. The former is calculated as the natural logarithm of the quantity of $\mathrm{CP}$ activities plus 1 to minimise the influence of highly skewed data (Wang \& Qian, 2011), and the latter is calculated as the percentage contribution of $\mathrm{CP}$ to total revenue to eliminate the influence of firm scale.

Based on the above hypotheses, four main independent variables are proposed. The first is a dummy variable that equals 1 for attraction companies and 0 for paired companies, simply and clearly differentiating community expectations of these two kinds of company. Second, the economic divergence between the local community and surrounding urban districts is measured by the ratio of annual income between urban and rural residents. This index is reasonable, as the communities surrounding the tourism attractions under study are all located in rural areas. Third, the area of a tourist attraction site is used as a proxy for the competition for tourism opportunities in the surrounding community. A larger attraction site has larger bordering communities, attracting more small businesses to compete in providing complementary services for visitors at the main attraction. Therefore, more small local businesses in bordering communities engage in greater competition for the business opportunities brought by a larger attraction. This variable is transformed using the natural logarithm, with a higher value indicating greater competition. Last, the concentration of primary education is calculated as a ratio of the number of primary schools to the size of the local area. The bigger the variable, the less scarce the community's educational resources. Here, only primary schools are used to reflect the imbalance in educational resources between regions. This is related to the background of the Chinese compulsory education system reform since 1985 (Zhou, 2015). Most middle and high schools are concentrated in towns and cities, with only primary schools in rural areas. In addition, the moderating variable (TourC) of the economic contribution of tourism is calculated as the share of total 
tourism revenue in the local gross domestic product (GDP).

Following previous studies (e.g. Chen et al., 2015; Gautier $\&$ Pache, 2015; Liket $\&$ Simaens, 2015), determinants of CP are introduced as control variables based on statistical justifications, sample characteristics and the Chinese context. The first is a macroeconomic variable measuring the influence of the local economy, calculated using the natural logarithm of the per capita GDP (PGDP) of each region. According to the literature, firms located in areas with more developed economies are more likely to donate (Salamon \& Sokolowski, 2004). Additional variables are introduced to reflect firm characteristics. The size of an attraction company is measured as the natural logarithm of its total assets (Asset). Although size has been recognised as an important factor in many studies, its influence on $\mathrm{CP}$ has been found to be variously positive, not significant or even cubic (Chen et al., 2015; Wang \& Qian, 2011). The ratios of return on assets (ROA) and operational cash per share (Cash) are both included due to the potential influence of corporate profitability and cash flow on CP based on slack resource theory (Tan $\&$ Tang, 2016). Positive relationships have been found between these ratios and CP (Liket $\&$ Simaens, 2015). A leverage ratio has also been included in many previous studies due to its possible negative influence on $C P$ (Brammer \& M illington, 2005; Chen et al., 2015; Tan \& Tang, 2016). The leverage ratio has been operationalised as the ratio of a firm's total debt to its total assets (Debt). In the transitional Chinese context, state-owned enterprises (SOEs) are thought to take more responsibility for promoting social stability and community harmony than non-SOEs (Chen et al., 2015). Thus, a variable that equals 1 if a firm is an SOE and 0 otherwise is introduced to gauge the influence of different firm types on CP behaviour. In the sample period, two special events, i.e., severe acute respiratory syndrome (SARS) in 2003 and the Wenchuan earthquake in 2008, had countrywide effects on either tourism firms' profits or public attention to CP (Wang $\&$ Xu, 2009). Following Zhang (2002), two dummy variables (E1 and E2) are introduced to capture the influence of these events on firms' CP. Last, as discussed in Section 2, the moderating variable TourC may directly influence $\mathrm{CP}$ in addition to moderating the associations between community causes and CP. Therefore, both direct and moderating effects on CP are examined.

Regression models 1-3 test the direct effects of community-related features on CP hypothesised in Section 2. The subscripts $i$ and tenote the firm and year in each model, respectively. For $\mathrm{H} 1$, the community feature in models $1-3$ is the only attraction dummy variable, and the control variables are all those proposed above. All observations of the listed attraction and paired companies are included in the analysis. For $\mathrm{H} 2 \mathrm{a}$ to $\mathrm{H} 2 \mathrm{C}$, community features comprise three variables (economic divergence, competition for tourism business and educational resources) and all of the control variables discussed above except for the SOE variable, which equals 1 for almost all observations (i.e. state-owned). To control for endogeneity in the models, the value t- 1 is used for all of the firm-level control variables (Chen et al., 2015; Tan \& Tang, 2016). In addition, to test H2a to H2c, only 
observations on listed attraction companies are included in the models.

Model 1: $\mathrm{DPhi}_{\mathrm{i}, \mathrm{t}}=\alpha+\beta$ Community Features $_{i, t}+\gamma$ Control Variables ${ }_{i, t-1}+\varepsilon$

Model 2: $\operatorname{LnPhi}_{\mathrm{i}, \mathrm{t}}=\alpha+\beta$ Community Features ${ }_{i, t}+\gamma$ Contral Variables $_{i, t-1}+\varepsilon$

Model 3: PhiR $_{\mathrm{i}, \mathrm{t}}=\alpha+\beta$ Community Features $_{i, t}+\gamma$ Control Variables $_{i, t-1}+\varepsilon$

In line with the literature (de-Miguel-Molina, Chirivella-Gonzalez, \& Garcia-Ortega, 2016), the probit method is used for Model 1 due to the dummy-dependent variable Dphi. The probit method is a statistical method designed to adjust a regression model in which the dependent variable characterises an event with only two possible results, 1 or 0 , where 1 indicates the likelihood of one of these two possible results (de-M iguel-M olina et al., 2016; Wang \& Qian, 2011). In models 2 and 3, the dependent variables (LnPhi and PhiR, respectively) are censored variables that cannot be negative. A tobit model is the method most commonly used with this kind of sample (Brammer \& Millingtonn, 2006), and is used here to estimate models 2 and 3.

Model 4: DPhi $_{\mathrm{i}, \mathrm{t}}=\alpha+\beta$ Community Features ${ }_{i, t}+\gamma$ Community Features $_{i, t} \times$ $\operatorname{TourC}_{i, t}+\theta \operatorname{TourC}_{i, t}+\delta$ Control Variables $i, t-1+\varepsilon$

Model 5: $\operatorname{LnPhi}_{\mathrm{i}, \mathrm{t}}=\alpha+\beta$ Community Features $_{i, t}+\gamma$ Community Features $_{i t} \times$

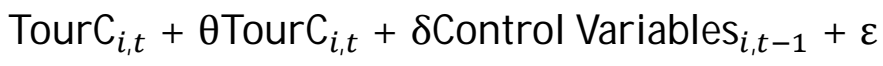

Model 6: $\mathrm{PhiR}_{\mathrm{i}, \mathrm{t}}=\alpha+\beta$ Community Features ${ }_{i, t}+\gamma$ Community Features $_{i t} \times$ $\operatorname{TourC}_{i, t}+\theta_{\text {TourC }} C_{i, t}+\delta$ Control Variables $i, t-1+\varepsilon$

Models 4- 6 are specified to test $\mathrm{H} 3$, which emphasises the moderating effect of TourC. This variable is listed separately in the model, and the other variables included in models 4 -6 are the same as in previous models. For the same reasons as noted for the dependent variables in models 1-3, the probit method is used for model 4 and the tobit model is used for models 5 and 6 . Models 4 - 6 use only attraction company observations.

\section{Further support through interviews}

The interviews with the listed attraction companies' top managers were expected to provide supplementary evidence and a more in-depth understanding of the statistical tests. The main interview questions were as follows: "To which fields do your company's donations go?", "What are the reasons/purposes for your company's donations to the community?" and "Could you provide typical cases of your company's donation?" Each interview was approximately 30 minutes long. All of the nine listed attraction companies included in the quantitative analysis were first contacted to request interviews. Despite great challenges to the arrangement of interviews with the top managers of the listed companies, five positive responses were received, and thus five interviews were conducted between October 2016 and February 2017. The five interviewed companies represented the leading listed attraction 
companies dispersed across China.

\section{Empirical results}

\section{Descriptive statistics}

Parts $A$ and $B$ of Table 1 provide descriptive statistics and the Pearson correlation matrix for the main variables used to test $\mathrm{H} 1$ and $\mathrm{H} 2 \mathrm{a}$ to $\mathrm{H} 2 \mathrm{C}$, respectively. The mean values of the three dependent variables (DPhi, LnPhi and PhiR) in Part B are higher than their counterparts in Part $A$. This shows that the listed attraction companies may be more active in CP activities than other tourism companies. In addition, as shown in Parts A and B of Table 1 , all of the correlation coefficients are lower than the threshold value of 0.7 , the most common criterion for assessing multicollinearity (Dormann et al., 2013). Correlation coefficient values higher than 0.7 indicate collinearity with the potential to severely distort model estimations and subsequent predictions. Following previous studies (Allison, 1999; Wang \& Qian, 2011), variance inflation factors (VIF) are calculated for each variable to determine whether a multicollinearity problem exists. The highest VIF obtained for the model testing $\mathrm{H} 1$ is 2.065 (PGDP); the others are approximately 1 . The highest VIF obtained for the models testing Hypotheses $2 a$ to $2 c$ is 4.129 (PGDP); the others are approximately 2. The two top VIF values are both below the rule-of-thumb threshold of 5.00 for regression models. Therefore, multicollinearity is not an issue in this study.

\section{\{nsert Table 1 about here\}}

\section{Overall community effects on CP}

Before further empirical tests, the study examines the potential heteroscedasticity and simultaneity of each model. No evidence of these problems is obtained through a set of tests suggested in the literature (Brammer \& M illingtonn, 2006). Table 2 reports the results for $\mathrm{H} 1$. The coefficient of the attraction dummy variable is 1.163 , significant at the 0.01 significance level in sub-model 1 (Table 2). As expected, the listed attraction companies are more likely than other tourism companies to donate to surrounding communities. In addition, the coefficients of the attraction dummy variable are both positive and significant in sub-models 2 (7.906, $p<0.01)$ and $3(0.418, p<0.01)$. This illustrates that the listed attraction companies are more likely to make larger donations as their CP behaviour increases, in both absolute and relative terms. These findings effectively support $\mathrm{H} 1$, according to which attraction companies engage in CP more actively than other tourism companies.

\{nsert Table 2 about here\}

Table 2 also reports the empirical results for the control variables. The coefficient of 
TourC is positive and significant in each model. This suggests that attraction companies located in regions with more tourism tend to donate more than other types of tourism company. The positive finding for PGDP aligns with the results of previous studies (Salamon $\&$ Sokolowski, 2004). Similarly, the observed effects of firm profitability, cash flow and firms' state-owned nature on CP confirm the findings of previous research (Chen et al., 2015; Tan \& Tang, 2016). In addition, the significant positive result for E2 supports the argument that severe disasters are likely to increase both the likelihood of a firm's donating and the size of its donations (Crampton \& Patten, 2008). The Wenchuan earthquake, a serious disaster in Sichuan province, made many enterprises enthusiastic about donating. In contrast, firms' CP behaviour was not influenced by the SARS outbreak in 2003. The coefficients for Debt $n_{n-1}$ in sub-models 2 and 3 (Table 2) are positive, unlike those obtained in previous studies (Brammer \& Millington, 2005; Tan \& Tang, 2016). These results reflect the highly leveraged capital structure of Chinese attraction companies. To maintain their high debt-financing ability, attraction companies actively implement CP measures to sustain good relationships with both communities and local governments (Chen et al., 2015). In addition, the influence of size is found to be nonsignificant, in contrast with the findings of previous studies (Tan \& Tang, 2016; Wang $\&$ Qian, 2011). This may be due to the fact that attraction companies are generally similar in size.

\section{Further tests of the associations between community features and CP}

Table 3 presents the results for the effects of community features on the attraction companies' CP behaviour. All of the coefficients of the economic divergence variable in sub-models 1-3 are positive and significant. This indicates that an increase in the local community's economic divergence increases not only the possibility of an attraction company engaging in $\mathrm{CP}$ activities, but also the size of its donations. These results support H2a. Similarly, the positive effects of community competition are proven. Fierce competition within communities increases both attraction companies' probability of donating and their donation value. $\mathrm{H} 2 \mathrm{~b}$ is thus supported. The negative results for educational resources are also consistent with $\mathrm{H} 2 \mathrm{c}$, according to which communities' scarcity of educational resources stimulates attraction companies' CP behaviour. This result is also consistent with previous findings in the Chinese context (Ledingham \& Bruning, 2001).

\{nsert Table 3 about here\}

The moderating effects are reported in Table 4. The lists of regressions are estimated according to models $4-6$ to determine how tourism affects the relationships between community features and firms' CP behaviour. In Table 4, only the results for the dependent variables Dphi and LnPhi are included. The economic contribution of tourism has no significant effect on the relationship between any community feature and the PhiR variable. After adjusting for firms' revenue scales, the relative value of donations is very low, with a 
mean of only $3.573 \%$. This may limit the significance of the moderating effect of tourism.

\section{\{nsert Table 4 about here\}}

With regard to the likelihood of attraction companies donating, the coefficients of both EDxTourC $(-1.857, p<0.1)$ and $B C \times \operatorname{TourC}(-1.633, p<0.1)$ are negative and significant. These findings suggest that listed attraction companies located in regions with low economic dependence on tourism are more likely to donate if their surrounding communities lag behind and are close to large tourist attractions. These results support H3. However, the coefficient of $E R \times$ TourC is not statistically significant. This is probably due to the significant emphasis placed on education in Chinese society (Zhou, 2015), which increases attraction companies' intention to donate to support communities with scarce educational resources.

Second, tobit analysis of the absolute levels of attraction companies' donations reveals that the relationship between community competition and $\mathrm{CP}$ is not significantly affected by the economic contribution of tourism. However, the significant coefficient of EDx TourC indicates that listed attraction companies in regions with low economic dependence on tourism donate more to local communities with greater economic divergence. As proposed in $\mathrm{H} 3$, this may be due to these firms' weak negotiating power. In contrast with the results for firms' likelihood of donating, the coefficient of $E R \times T$ TourC is positive and significant. This means that the negative influence of primary educational resources on firms' donations is likely to be weaker if attraction companies are located in regions in which the tourism industry dominates the local economy. This also supports $\mathrm{H} 3$, as attraction companies tend to decrease their donations through negotiation with local governments. Overall, H3 is supported.

Finally, the coefficients of TourC are negative (see Tables 3 and 4). Although the attraction companies are found to engage in $\mathrm{CP}$ more actively than the paired tourism companies, attraction companies in more tourism-dependent regions tend to have more negotiating power over local governments, making CP less necessary as a business strategy. The findings for the other control variables in Tables 3 and 4 are consistent with the results in Table 2.

\section{Further support from the interview results}

To illustrate the above findings and gain further insights, interviews with five top managers of the listed companies were conducted.

First, the empirical findings on the influence of economic divergence were illustrated and supported by the interviews. The most frequent descriptor of their local communities used by the top managers was "less developed". In one of the interviews, the top manager of a company operating a main attraction in a less developed area and a few small tourist attractions in a developed area commented as follows. "We tend to donate to economically less developed communities. We rarely give to communities in developed areas" 
(Interviewee No. 5). The top managers also noted that "conflict between tourist attraction companies and their surrounding communities is common in China" and that "this conflict is generally related to the pursuit of economic benefits by backward communities" (Interviewee No. 4). Attraction companies are thus able to avoid conflict by providing funds that enable local villages to build infrastructure or by directly helping them to improve their skills in developing agriculture or small tourism businesses (Interviewees Nos 1-3). This finding also indicates that the economic situation of surrounding communities is an important determinant of attraction companies' CP decisions.

Second, the presence of large-scale unorganised small businesses in surrounding communities was highlighted by the top managers. "The attraction operated by our company is large and surrounded by several villages. We thus face the big challenge of balancing the complicated relationships between them" (Interviewee No. 2). One factor responsible for these complicated relationships is competition between villages (Xu et al., 2016). Attraction companies must engage in CP to smooth their relationships with their local communities and thereby facilitate their operations. This is consistent with both our hypothesis and the finding of the quantitative analysis that community competition is an indirect driver of firm donation.

Third, funding for local education was emphasised by all of the top managers interviewed. Such educational support provides for scholarships at local schools for excellent students from poor families, the maintenance of school buildings and facilities, etc. (Interviewees Nos 1-5). According to one top manager, local "school facilities are old and insufficient; the local community warmly welcomes our donations to schools" (Interviewee No. 3). The companies tend to respond to the call of local governments to support education in their rural communities, making up for local governments' failure to provide sufficient educational resources (Interviewees Nos 3-5). The results of the interviews support the finding of the regression analysis that a lack of educational resources is a key driver of CP.

In addition to these specific community factors, two overall factors driving attraction companies' CP decisions were identified from the interviews: "building good relationships" and "reducing collisions" with surrounding communities (Interviewees Nos 1-5). Relationships with local communities were highlighted in every interview. The managers expected to forge good relationships not only with their communities, but also with their local governments. For example, one top manager noted that "the target of our active social responsibility behaviour is to build a good corporate image and relationships with the community; this helps to decrease conflict [with the local community] and is good for our firm's operations" (Interviewee No. 4). Another interviewee added that "this activity [i.e., donation] is favoured by the local government ... [After donating,] we get more support from the government for our operations (Interviewee No. 2). The findings of the interviews support our hypothesis that attraction companies engage more actively in CP than other 
tourism companies, based on our legitimacy strategy framework. Despite these benefits, the interviewees acknowledged that $\mathrm{CP}$ is costly and that companies do not always intend to engage in CP activities. "Every donation must be audited with a list of strict rules and approved in shareholder meetings. Sometimes this forces us to negotiate with the local government to save costs" (Interviewee No. 4). This result encourages us to consider the moderating effects of firms' discursive power in negotiating with local governments.

The findings of this study support the premise that CP offers an effective tool for attraction companies seeking to increase their societal legitimacy and sustain their operations. The findings also reveal that attraction companies' CP is consistent with communities' sustainable development goals. According to the sustainability agenda of the UN (2015), the implications of these findings for sustainability are as follows. First, attraction companies' CP has an important economic implication. Due to the leading role of listed attraction companies and their important contribution to the tourism industry, their continuous development is key to the development of the Chinese tourism industry. Second, attraction companies' CP has comprehensive social implications for communities. Through actions such as donating to education or helping poor families (Interviewees Nos 1-3), providing funds enabling communities to build infrastructure or helping communities to develop agriculture, forestry or even small tourism businesses (Interviewee Nos 1 and 3), the community can move towards sustainability by improving its economy and quality of life (Polonsky et al., 2013).

\section{Conclusion}

Although the literature has generally linked CP with communities, no research to date has empirically examined whether or how a community may affect a firm's CP. This study investigates this issue in the Chinese transitional context by adopting a strategic legitimacy framework. Analysis of a sample of listed Chinese attraction companies reveals that these companies engaged in $\mathrm{CP}$ more actively than other listed tourism companies. Further testing indicates that certain community features, such as divergence within a dual economy, fierce competition for tourism business opportunities and scarce educational resources, significantly drive attraction companies' CP behaviour. In addition, the contributions of tourism to local economies are found to have moderating effects on the relationships between community features and listed tourism companies' overall CP behaviour.

Therefore, it is important to promote attraction companies' CP. As an important element of CSR (Liket \& Simaens, 2015), the execution of social responsibility through CP is often confused with the social functions of China's SOEs, especially because most attraction companies are state-owned. The drive to "take away social functions from state-owned enterprises" has been promoted since the end of the twentieth century, seeking to remove firms' social burden and focus on their operational business. However, our study argues for 
the need to take another look at this issue. The "social functions" of attraction companies operating on public tourism resources and subject to high expectations from society are greatly needed by local communities with insufficient public resources. CP offers an effective approach to fulfilling CSR, as it does not interfere with firms' business operations and can help them to build extensive relationships with the public. Firms should fulfil their social responsibilities actively through $\mathrm{CP}$ and thereby bring benefits to both their local communities and themselves.

This study makes some contributions to the literature on CP. First, it represents the first attempt to examine the community-related factors that influence $\mathrm{CP}$, which have been overlooked in previous studies. The study identifies three community factors affecting firms' $\mathrm{CP}$, namely economic divergence, level of competition within the community and the adequacy of primary educational resources. Therefore, the study provides further insights into the drivers of $\mathrm{CP}$ from the community perspective. Second, the study demonstrates the moderating effects of the economic contribution of tourism on the relationships between community factors and $\mathrm{CP}$, and provides further understanding of the motivation for $\mathrm{CP}$ from a macroeconomic perspective. Third, it enriches the literature on the CP of tourism enterprises. Although CP has received increasing attention in other fields, such as management, economics, sociology and public policy, very little research has investigated CP in the tourism industry. In contrast with studies of the hotel sector, this study focuses on tourism firms operating on public resources in the Chinese context. The close relationships between these firms and their surrounding communities are investigated under the legitimacy strategy framework, which broadens our understanding of tourism enterprises' $\mathrm{CP}$ behaviour and motivations.

This study has some limitations, but also indicates directions for future research. First, due to limitations on data availability, only nine Chinese listed attraction companies are included in the study. Second, also due to data limitations, only three community factors are considered. Other community-related factors may also drive CP. Future research should extend the list of these factors where data availability allows. Last, as this study provides an example of $\mathrm{CP}$ in only one transitional economic entity, China, the impact of communities on $\mathrm{CP}$ in other countries should be investigated to draw more generalisable conclusions.

\section{References}

Allison, P. (1999). M ultiple regression: a primer. Thousand Oaks, CA: Sage Publications.

Bai, Y. (2014,July ). Analysis on the network consensus on villagers around Emeishan National Park asking for rights by blocking road. Retrieved from http://yuqing.people.com.cn/n/2014/0708/c210114-25254554.html. 
Bowen, F., Newenham-Kahindi, A., \& Herremans, I. (2010). When suits meets roots: the antecedents and consequences of community engagement strategy. Journal of Business Ethics, 95, 297-318.

Brammer, S., \& Millington, A. (2005). Corporate reputation and philanthropy: an empirical analysis. Journal of Business Ethics, 61(1), 29-44.

Brammer, S., \& Millington, A. (2006). Firm size, organizational visibility and corporate philanthropy: an empirical analysis. Business Ethics: A European Review, 15(1), 6-18.

Bronn, P. S., \& Vidaver-Cohen, D. (2009). Corporate motives for social initiative: legitimacy, sustainability, or the bottom line? Journal of Business Ethics, 87, 91-109.

Cao, C. F., \& Fu, C. (2015). Official tenure and local SOE donations: do officials pursue "charity"? Journal of Finance and Economics, 41(4), 122-133.

Carroll, A. B., 1991. The pyramid of corporate social responsibility: toward the moral management of organizational stakeholder. Business Horizons, 34, 39-48.

Chen, D. H., Jiang, D. Q., \& Yu, X. (2015). Corporate philanthropy and bank loans in China. Pacific-Basin Finance Journal, 35, 402-424.

Chen, Z. S., \& Cao, Y. (2016). Chinese private corporate philanthropy: social responsibility, legitimacy strategy, and the role of political capital. Chinese Sociological Review, 48(2), 108-136.

Crampton, W., \& Patten, D. (2008). Social responsiveness, profitability and catastrophic events: evidence on the corporate philanthropic response to 9/11. Journal of Business Ethics, 81, 863-873.

de-Miguel-Molina, B., Chirivella-Gonzalez, V., \& Garcia-Ortega, B. (2016). Corporate philanthropy and community involvement. Analysing companies from France, Germany, the Netherlands and Spain. Quality \& Quantity: International Journal of M ethodology, 50(6), 2741-2766.

Dormann, C. F., Elith, J., Bacher, S., et al. (2013). Collinearity: a review of methods to deal with it and a simulation study evaluating their performance. Ecography, 36(1), 027-046.

Gautier, A., \& Pache, A. C. (2015). Research on corporate philanthropy: a review and assessment. Journal of Business Ethics, 126, 343-369.

Guthrie, D., Arum, R., Roksa, J., \& Damaske, S. (2008). Donation to local schools: corporate philanthropy, tax incentives, and ecology of need. Social Science Research, 37, 856-878.

Hedin, L. T., \& Ranangen, H. (2017). Community involvement and development in Swedish mining. The Extractive Industries and Society,.

Hill, R. P., Stephens, D., \& Smith, I. (2003). Corporate social responsibility: an examination of individual firm behavior. Business and Society Review, 108(3), 339-364.

Ledingham, J. A., \& Bruning, S. D. (2001). Managing community relationships to maximize mutual benefit: doing well by doing good. In R. L. Heath (Ed.), Handbook of public relations (pp. 527-534). Thousand Oaks, CA: Sage Publications.

Li, J., \& Zhao, L. (2015). The costs of socializing with government officials: A new measure of 
corporate political connections. China Journal of Accounting Research, 8 (1), 25-39.

Liket, K., \& Simaens, A. (2015). Battling the devolution in the research on corporate philanthropy. Journal of Business Ethics, 126, 285-308.

Marquis, C., Glynn, M. A., \& Davis, G. F. (2007). Community isomorphism and corporate social action. Academy of Management Review, 32(3), 925-945.

Novelli, M., M organ, N., M itchell, G., \& Ivanov, K. (2015). Travel philanthropy and sustainable development: the case of the Plymouth Banjul Challenge. Journal of Sustainable Tourism, 24 (6), 824-845.

Polonsky, M., Hall, J., Vieceli, J., Atay, L., Akdemir, A., \& Marangoz, M. (2013). Using strategic philanthropy to improve heritage tourist sites on the Gallipoli Peninsula, Turkey: community perceptions of changing quality of life and of the sponsoring organization. Journal of Sustainable Tourism, 21(3), 376-395.

Ryan, C., Zhang, C. Z., \& Deng, Z. (2011). The impacts of tourism at a UNESCO heritage site in China-a need for a meta-narrative? The case of the Kaiping Diaolou. Journal of Sustainable Tourism, 19(6), 747-765.

Saiia, D., Carroll, A., Buchholtz, A., 2003. Philanthropy as strategy: when corporate charity "begins at home". Business \& Society, 42 (2), 169-201.

Salamon, L. M., \& Sokolowski, W. (2004). Global civil society: dimension of the nonprofit sector. Volume two. Bloomfield: Kumarian Press.

Sethi, S. P. (1979). A conceptual framework for environmental analysis of social issues and evaluation of business response patterns. Academy of M anagement Review, 4, 63-74.

Suchman, M. C. (1995). Managing legitimacy: strategic and institutional approaches. Academy of Management Review, 20(3), 571-610.

Tan, J., \& Tang, Y. J. (2016). Donate money, but whose? An empirical study of ultimate control rights, agency problems, and corporate philanthropy in China. Journal of Business Ethics, 134, 593-610.

Thorne, D. M., Ferrell, O. C., \& Ferrell, L. (2003). Business and society: a strategic approach to corporate citizenship. Boston, M A: Houghton M ifflin, p. 360.

United Nations (UN). (2015). Transforming our world: The 2030 agenda for sustainable development. Retrieved from

https:// sustainabledevelopment.un.org/content/documents/21252030\%20Agenda\%20 for\%20Sustainable\%20Devel opment\%20web.pdf

Van Cranenburgh, K., \& Arenas, D. (2014). Strategic and moral dilemmas of corporate philanthropy in developing countries: Heineken in Sub-Saharan Africa. Journal of Business Ethics, 122, 523-536.

Wang, C. P., \& Xu, H. G. (2009). On the impact of important events on the performance of China's market of tourism listed companies: taking the year 2008 as an example. Tourism Tribune, 7, 58-65.

Wang, C. P., \& Xu, H. G. (2014). The role of local government and the private sector in 
China's tourism: the issue of sustainability. Tourism Management, 45, 95-105.

Wang, H., \& Qian, C. (2011). Corporate philanthropy and corporate financial performance: the roles of stakeholder response and political access. Academy of Management Journal, 54, 1159-1181.

Weeden, C. (2015). Legitimization through corporate philanthropy: a cruise case study. Tourism in Marine Environments, 10(3-4), 201-210.

Xu, H. G., Zhu, D., \& Bao, J. G. (2016). Sustainability and nature-based mass tourism: lessons from China's approach to the Huangshan Scenic Park. Journal of Sustainable Tourism, 24(2), 182-202.

Zhang, G. L., Zhu, W. Z., \& Hua, X. (2013). Charity behavior features and effect evaluation of coal enterprise. Coal Economic Research, 33(3), 45-47.

Zhang, J. (2002). Capital formation, industrial, economic growth: Chinese transitional characteristics. Economic Research Journal, 6, 3-13.

Zhou, H. Q. (2015). Corporate philanthropy in contemporary China: a case of rural compulsory education promotion. Voluntas: International Journal of Voluntary and Nonprofit Organizations, 26, 1143-1163. 
Table 1 Pearson correlation results for main variables

\begin{tabular}{|c|c|c|c|c|c|c|c|c|c|c|}
\hline \multicolumn{11}{|c|}{ Part A: All tourism listed companies } \\
\hline & Mean & STD & Obs & 1 & 2 & 3 & 4 & 5 & 6 & 7 \\
\hline 1. Dphi & 0.627 & 0.484 & 377 & 1 & & & & & & \\
\hline 2. LnPhi & 7.377 & 5.960 & 377 & $0.950^{* * * *}$ & 1 & & & & & \\
\hline 3. PhiR & 0.178 & 0.040 & 377 & $0.340^{* * * *}$ & $0.464^{* * * *}$ & 1 & & & & \\
\hline $\begin{array}{l}\text { 4. Attraction } \\
\text { dummy }\end{array}$ & 0.271 & 0.445 & 377 & $0.270^{* * *}$ & $0.289^{* * * *}$ & $0.306^{* * *}$ & 1 & & & \\
\hline 5. TourC & 0.232 & 0.223 & 377 & $0.208^{* * *}$ & $0.242^{* * *}$ & $0.362^{* * *}$ & $0.530^{* * *}$ & 1 & & \\
\hline 6. PGDP & 10.566 & 0.889 & 377 & 0.015 & 0.023 & $-0.132^{* *}$ & $-0.564^{* * * *}$ & $-0.318^{* * *}$ & 1 & \\
\hline 7. $\mathrm{ROA}_{\mathrm{n}-1}$ & 0.038 & 0.083 & 343 & $0.130^{* *}$ & $0.167^{* * * *}$ & $0.133^{* *}$ & 0.055 & 0.065 & 0.052 & 1 \\
\hline 8. Asset ${ }_{n-1}$ & 21.167 & 1.318 & 343 & -0.011 & 0.006 & $-0.092^{*}$ & $-0.233^{* * * *}$ & $-0.291^{* * *}$ & $0.464^{* * * *}$ & 0.051 \\
\hline 9. Cash $_{n-1}$ & 0.417 & 0.504 & 343 & $0.250^{* * * *}$ & $0.269^{* * * *}$ & 0.048 & 0.056 & 0.051 & 0.088 & $0.231^{\text {****}}$ \\
\hline 10. Debt $_{n-1}$ & 0.436 & 0.224 & 346 & 0.048 & 0.064 & 0.036 & $-0.093^{*}$ & 0.068 & 0.083 & $-0.258^{* * *}$ \\
\hline 11. SOEs & 0.764 & 0.425 & 377 & $0.128^{* *}$ & $0.148^{* * *}$ & 0.062 & $0.227^{* * * *}$ & 0.053 & $-0.272^{* * *}$ & 0.057 \\
\hline \multicolumn{11}{|c|}{ Part B: Listed attraction companies } \\
\hline & Mean & STD & Obs & 1 & 2 & 3 & 4 & 5 & 6 & 7 \\
\hline 1. Dphi & 0.84 & 0.372 & 98 & 1 & & & & & & \\
\hline 2. LnPhi & 10.067 & 4.863 & 98 & $0.919^{* * * *}$ & 1 & & & & & \\
\hline 3. PhiR & 3.573 & 6.037 & 98 & $0.263^{* * * *}$ & $0.439^{* * * *}$ & 1 & & & & \\
\hline $\begin{array}{l}\text { 4.Economic } \\
\text { divergence }\end{array}$ & 3.085 & 0.975 & 96 & $0.215^{* *}$ & $0.288^{* * * *}$ & $0.565^{* * *}$ & 1 & & & \\
\hline $\begin{array}{l}\text { 5.Business } \\
\text { competition }\end{array}$ & 8.886 & 2.606 & 98 & 0.087 & 0.122 & $0.257^{* *}$ & 0.114 & 1 & & \\
\hline $\begin{array}{l}\text { 6.Education } \\
\text { resource }\end{array}$ & 0.060 & 0.052 & 98 & $-0.326^{* * *}$ & $-0.374^{* * *}$ & $-0.349^{* * *}$ & 0.011 & -0.107 & 1 & \\
\hline 7. TourC & 0.426 & 0.286 & 96 & 0.163 & $0.232^{* *}$ & $0.324^{* * *}$ & $0.172^{*}$ & $0.578^{* * *}$ & $-0.442^{* * *}$ & 1 \\
\hline 8. PGDP & 9.69 & 0.714 & 98 & 0.091 & 0.135 & -0.115 & $-0.581^{* * * *}$ & $-0.329^{* * *}$ & $-0.372^{* * *}$ & 0.077 \\
\hline 9. $\mathrm{ROA}_{\mathrm{n}-1}$ & 0.357 & 0.604 & 98 & $0.263^{* * *}$ & $0.439^{* * * *}$ & $1.00^{* * * *}$ & $0.565^{* * *}$ & $0.257^{* *}$ & $-0.349^{* * * *}$ & $0.324^{* * *}$ \\
\hline 10. Asset ${ }_{n-1}$ & 20.667 & 0.675 & 93 & 0.053 & 0.112 & $-0.302^{* * *}$ & $-0.441^{* * * *}$ & -0.122 & -0.078 & $0.211^{* *}$ \\
\hline 11. Cash $_{n-1}$ & 0.464 & 0.398 & 93 & $0.211^{* * *}$ & $0.286^{* * *}$ & 0.155 & 0.100 & 0.026 & -0.002 & $0.248^{* * *}$ \\
\hline 12. $\operatorname{Debt}_{n-1}$ & 0.403 & 0.211 & 93 & 0.115 & 0.071 & 0.073 & 0.029 & 0.088 & -0.142 & 0.048 \\
\hline
\end{tabular}

Note: The amount donated by Lijiang Tourism in 2012 is adjusted downward by 2 million Chinese yuan, as it was for denote significant results at the $0.10,0.05$ and 0.01 significance levels, respectively. 
Table 2 Regression results of the overall influence of community on CP

\begin{tabular}{|c|c|c|c|}
\hline Variables & (1) DPhi & (2) LnPhi & (3) PhiR \\
\hline Constant & $\begin{array}{l}-4.725^{* * *} \\
(-2.904)\end{array}$ & $\begin{array}{c}-31.627^{* * *} \\
(-3.217)\end{array}$ & $\begin{array}{l}-1.473^{* *} \\
(-2.026)\end{array}$ \\
\hline Attraction dummy & $\begin{array}{l}1.163^{* * * *} \\
(4.119)\end{array}$ & $\begin{array}{l}7.906^{* * *} \\
(5.646)\end{array}$ & $\begin{array}{l}0.418^{* * * *} \\
(4.538)\end{array}$ \\
\hline TourC & $\begin{array}{l}1.061^{* *} \\
(2.091)\end{array}$ & $\begin{array}{l}3.986^{* *} \\
(1.966)\end{array}$ & $\begin{array}{l}0.592^{* * * *} \\
(2.861)\end{array}$ \\
\hline PGDP & $\begin{array}{l}0.480^{* * * *} \\
(3.574)\end{array}$ & $\begin{array}{l}3.663^{* * * *} \\
(4.645)\end{array}$ & $\begin{array}{l}0.150^{* * * *} \\
(2.795)\end{array}$ \\
\hline $\mathrm{ROA}_{\mathrm{n}-1}$ & $\begin{array}{l}1.021 \\
(0.941)\end{array}$ & $\begin{array}{l}7.894^{*} \\
(1.767)\end{array}$ & $\begin{array}{c}0.679 \\
(1.441)\end{array}$ \\
\hline Asset $_{n-1}$ & $\begin{array}{l}-0.062 \\
(-0.940)\end{array}$ & $\begin{array}{l}-0.514 \\
(-1.251)\end{array}$ & $\begin{array}{l}-0.030 \\
(-1.115)\end{array}$ \\
\hline Cash $_{n-1}$ & $\begin{array}{l}0.567^{* * * *} \\
(3.065)\end{array}$ & $\begin{array}{l}3.096^{* * * *} \\
(3.405)\end{array}$ & $\begin{array}{c}0.064 \\
(1.177)\end{array}$ \\
\hline Debt $_{n-1}$ & $\begin{array}{c}0.489 \\
(1.315)\end{array}$ & $\begin{array}{l}4.646^{* *} \\
(2.275)\end{array}$ & $\begin{array}{l}0.263^{*} \\
(1.843)\end{array}$ \\
\hline SOEs & $\begin{array}{l}0.376^{* *} \\
(1.996)\end{array}$ & $\begin{array}{l}2.867^{*} \\
(3.346)\end{array}$ & $\begin{array}{l}0.106 \\
(1.457)\end{array}$ \\
\hline E1 & $\begin{array}{c}-0.119 \\
(-0.335)\end{array}$ & $\begin{array}{l}-1.202 \\
(-0.445)\end{array}$ & $\begin{array}{c}-0.043 \\
(-0.263)\end{array}$ \\
\hline E2 & $\begin{array}{l}1.060^{* * *} \\
(2.648)\end{array}$ & $\begin{array}{c}5.273^{* * * *} \\
(4.257)\end{array}$ & $\begin{array}{c}0.364^{* * * *} \\
(2.865)\end{array}$ \\
\hline Obs & 343 & $\begin{array}{c}\text { LnPhi } \leq 0 \text {, left censored obs is } \\
128 ; \text { uncensored obs is } 215\end{array}$ & $\begin{array}{c}\mathrm{PhiR} \leq 0 \text {, left censored obs is } \\
133 \text {; uncensored obs is } 210\end{array}$ \\
\hline Log Likelihood & -185.696 & -847.916 & -223.79 \\
\hline $\begin{array}{l}\text { McFadden } \\
\mathrm{R}^{2} / \text { Adjusted } \mathrm{R}^{2}\end{array}$ & 0.180 & 0.192 & 0.12655 \\
\hline
\end{tabular}

Note: Z-statistic values appear in brackets. The Attraction dummy is used to identify firm-related expectation gaps. $* * *$ and $* * *$ denote significant results at the $0.10,0.05$ and 0.01 significance levels, respectively. 
Table 3 The associations between community features and attraction companies' CP

\begin{tabular}{|c|c|c|c|}
\hline Variables & (1) DPhi & (2) LnPhi & (3) PhiR \\
\hline \multirow{2}{*}{ Constant } & $-17.018^{*}$ & $-57.522^{* * *}$ & -2.912 \\
\hline & $(-1.818)$ & $(-2.706)$ & $(1.266)$ \\
\hline \multirow{2}{*}{ Economic divergence } & $1.934^{* * *}$ & $2.870^{* * * *}$ & $0.554^{* * * *}$ \\
\hline & $(3.395)$ & $(3.602)$ & (9.912) \\
\hline \multirow{2}{*}{ Business competition } & $0.245^{* * *}$ & $0.593^{*}$ & $0.099^{* * * *}$ \\
\hline & $(2.777)$ & $(1.901)$ & $(4.850)$ \\
\hline \multirow{2}{*}{ Education resource } & $-16.823^{* * *}$ & $-45.674^{* * *}$ & $-4.497^{* * * *}$ \\
\hline & $(-3.994)$ & $(-2.676)$ & $(-3.875)$ \\
\hline \multirow{2}{*}{ TourC } & $-1.651^{* *}$ & $-7.959^{* *}$ & $-0.614^{* * *}$ \\
\hline & $(-1.973)$ & $(-2.454)$ & $(-2.900)$ \\
\hline \multirow{2}{*}{ PGDP } & 0.937 & 1.737 & $0.402^{* *}$ \\
\hline & $(1.551)$ & $(0.984)$ & $(2.510)$ \\
\hline \multirow{2}{*}{$\mathrm{ROA}_{\mathrm{n}-1}$} & $8.990^{* *}$ & $19.030^{*}$ & $2.260^{*}$ \\
\hline & $(2.395)$ & $(1.810)$ & (1.869) \\
\hline \multirow{2}{*}{ Asset $_{n-1}$} & 0.108 & $1.866^{*}$ & -0.142 \\
\hline & $(0.208)$ & $(1.801)$ & $(-0.940)$ \\
\hline \multirow{2}{*}{$\operatorname{Cash}_{\mathrm{n}-1}$} & $1.236^{*}$ & 2.385 & -0.104 \\
\hline & $(1.800)$ & $(1.221)$ & $(-0.653)$ \\
\hline \multirow{2}{*}{$\operatorname{Debt}_{\mathrm{n}-1}$} & 0.707 & $4.486^{*}$ & 0.236 \\
\hline & $(0.477)$ & $(1.741)$ & $(0.581)$ \\
\hline \multirow{2}{*}{ E1 } & 0.154 & -0.458 & 0.147 \\
\hline & $(0.151)$ & $(-0.144)$ & $(0.707)$ \\
\hline \multirow{2}{*}{ E2 } & $6.470^{* * * *}$ & 1.470 & 0.246 \\
\hline & (20.974) & (1.164) & (1.493) \\
\hline & 91 & LnPhi $\leq 0$, left censor & asored obs is 77 \\
\hline \multirow{2}{*}{$\begin{array}{l}\text { Log Likelihood } \\
\text { McFadden } \\
\mathrm{R}^{2} / \text { Adjusted R } \\
\end{array}$} & -20.988 & -237.926 & -43.691 \\
\hline & 0.463 & 0.291 & 0.609 \\
\hline
\end{tabular}

Note: Z-statistic values appear in brackets. ${ }^{*} * *$ and $* * *$ denote significant results at the 0.10 , 0.05 and 0.01 significance levels, respectively. 
Table 4 The moderating effects of the economic contribution of tourism

\begin{tabular}{|c|c|c|c|c|c|c|}
\hline \multirow{2}{*}{ Variables } & \multicolumn{3}{|c|}{ DPhi } & \multicolumn{3}{|c|}{ LnPhi } \\
\hline & (1) & (2) & (3) & (4) & (5) & (6) \\
\hline \multirow{2}{*}{ Constant } & -7.207 & 0.673 & $-16.393^{*}$ & -30.846 & -24.862 & -15.902 \\
\hline & $(-0.884)$ & $(0.042)$ & $(-1.685)$ & $(-1.600)$ & $(-1.245)$ & $(-0.593)$ \\
\hline \multirow{5}{*}{$\begin{array}{l}\text { Economic divergence } \\
\text { (ED) } \\
\text { Business competition } \\
\text { (BC) } \\
\text { Education resource } \\
\text { (ER) }\end{array}$} & $1.821^{* * * *}$ & $2.343^{* *}$ & $2.077^{* * * * *}$ & $4.909^{* * * *}$ & $2.464^{* * * *}$ & $2.306^{* *}$ \\
\hline & $(2.946)$ & (2.014) & $(3.052)$ & $(4.587)$ & (3.246) & $(2.561)$ \\
\hline & $0.259^{* * * *}$ & -0.575 & $0.272^{* * * *}$ & $0.756^{* * *}$ & -0.660 & 0.192 \\
\hline & (2.907) & $(-1.302)$ & (2.884) & $(2.382)$ & $(-0.661)$ & $(0.560)$ \\
\hline & $\begin{array}{c}-19.278^{* * *} \\
(-3.915)\end{array}$ & $\begin{array}{c}-21.685^{* * *} \\
(-2.686)\end{array}$ & $\begin{array}{l}-11.371^{*} \\
(-1.743)\end{array}$ & $\begin{array}{c}-57.479^{* * *} \\
(-3.427)\end{array}$ & $\begin{array}{c}-39.975^{* *} \\
(-2.013)\end{array}$ & $\begin{array}{l}-13.859 \\
(-0.579)\end{array}$ \\
\hline ED $\times$ TourC & $\begin{array}{l}-1.857 * \\
(-1.853)\end{array}$ & & & $\begin{array}{l}-6.891^{* * * *} \\
(-4.231)\end{array}$ & & \\
\hline $\mathrm{BC} \times$ TourC & & $\begin{array}{l}-1.633^{*} \\
(-1.666)\end{array}$ & & & $\begin{array}{l}-1.979 \\
(-0.911)\end{array}$ & \\
\hline $\mathrm{ER} \times$ TourC & & & $\begin{array}{l}16.953 \\
(1.100)\end{array}$ & & & $\begin{array}{l}66.798^{*} \\
(1.835)\end{array}$ \\
\hline TourC & $\begin{array}{c}-1.638^{* * * *} \\
(-0.281)\end{array}$ & $\begin{array}{c}1.943 \\
(1.290)\end{array}$ & $\begin{array}{l}-0.807^{*} \\
(-1.697)\end{array}$ & $\begin{array}{l}-4.981^{* *} \\
(-2.525)\end{array}$ & $\begin{array}{c}1.228 \\
(0.362)\end{array}$ & $\begin{array}{c}-0.205 \\
(-0.128)\end{array}$ \\
\hline PGDP & $\begin{array}{c}0.864 \\
(1.352)\end{array}$ & $\begin{array}{c}0.373 \\
(0.296)\end{array}$ & $\begin{array}{l}1.101^{*} \\
(1.837)\end{array}$ & $\begin{array}{l}2.935^{*} \\
(1.913)\end{array}$ & $\begin{array}{c}1.229 \\
(0.618)\end{array}$ & $\begin{array}{c}-0.249 \\
(-0.130)\end{array}$ \\
\hline $\mathrm{ROA}_{\mathrm{n}-1}$ & $\begin{array}{c}9.592^{* * *} \\
2.555\end{array}$ & $\begin{array}{l}10.174 \\
(1.556)\end{array}$ & $\begin{array}{l}9.288^{* *} \\
(2.423)\end{array}$ & $\begin{array}{l}13.412 \\
(1.209)\end{array}$ & $\begin{array}{l}20.840^{*} \\
(1.789)\end{array}$ & $\begin{array}{l}16.893^{*} \\
(1.672)\end{array}$ \\
\hline Asset $_{n-1}$ & $\begin{array}{c}-0.343 \\
(-0.737)\end{array}$ & $\begin{array}{c}-0.207 \\
(-0.316)\end{array}$ & $\begin{array}{l}-0.061 \\
(-0.135)\end{array}$ & $\begin{array}{c}-0.273 \\
(-0.373)\end{array}$ & $\begin{array}{c}0.991 \\
(1.069)\end{array}$ & $\begin{array}{c}0.759 \\
(0.800)\end{array}$ \\
\hline Cash $_{n-1}$ & $\begin{array}{l}1.444^{* * *} \\
(2.001)\end{array}$ & $\begin{array}{l}1.205^{*} \\
(1.633)\end{array}$ & $\begin{array}{l}1.113^{*} \\
(1.828)\end{array}$ & $\begin{array}{c}2.109 \\
(0.982)\end{array}$ & $\begin{array}{l}1.216 \\
(0.557)\end{array}$ & $\begin{array}{l}1.335 \\
(0.985)\end{array}$ \\
\hline $\operatorname{Debt}_{n-1}$ & $\begin{array}{c}2.383 \\
(1.418)\end{array}$ & $\begin{array}{c}0.612 \\
(0.185)\end{array}$ & $\begin{array}{c}1.200 \\
(0.810)\end{array}$ & $\begin{array}{c}1.811 \\
(0.681)\end{array}$ & $\begin{array}{l}5.544^{*} \\
(1.742)\end{array}$ & $\begin{array}{c}3.598 \\
(0.988)\end{array}$ \\
\hline E1 & $\begin{array}{c}0.351 \\
(0.330)\end{array}$ & $\begin{array}{c}0.409 \\
(0.466)\end{array}$ & $\begin{array}{c}0.269 \\
(0.256)\end{array}$ & $\begin{array}{c}0.435 \\
(0.149)\end{array}$ & $\begin{array}{l}-0.120 \\
(-0.039)\end{array}$ & $\begin{array}{c}0.073 \\
(0.030)\end{array}$ \\
\hline $\mathrm{E} 2$ & $\begin{array}{l}6.869^{* * * *} \\
(13.653)\end{array}$ & $\begin{array}{c}1.211 \\
(0.952)\end{array}$ & $\begin{array}{l}6.814^{* * * *} \\
(11.976)\end{array}$ & $\begin{array}{c}1.638 \\
(1.564)\end{array}$ & $\begin{array}{c}1.982 \\
(1.457)\end{array}$ & $\begin{array}{c}3.735^{*} \\
(1.831)\end{array}$ \\
\hline Obs & 91 & 91 & 91 & \multicolumn{3}{|c|}{$\begin{array}{c}\text { LnPhi } \leq 0 \text {, left censored obs is } 14 ; \\
\text { uncensored obs is } 77\end{array}$} \\
\hline Log Likelihood & -19.962 & -19.296 & -20.531 & -232.799 & -240.823 & -238.962 \\
\hline $\begin{array}{l}\text { McFadden } \mathrm{R}^{2} / \text { Adjusted } \\
\mathrm{R}^{2}\end{array}$ & 0.489 & 0.506 & 0.474 & 0.354 & 0.226 & 0.246 \\
\hline
\end{tabular}

Note: Z-statistic values appear in brackets. TourC is transformed to a dummy variable according to its median value for analyzing the moderating effect. Interactive terms are mean-centered to avoid multicollinearity. $* * *$ and $* * *$ denote significant results at the $0.10,0.05$ and 0.01 significance levels, respectively. 